\title{
Environmental-benign methods for the color protection of stripe long-shoot bamboo (Bambusa dolichoclada) culms
}

\author{
Min-Jay Chung, Sen-Sung Cheng, Shang-Tzen Chang* \\ School of Forestry and Resource Conservation, National Taiwan University, No. 1, Section 4, Roosevelt Road, Taipei 106, Taiwan
}

Received 21 June 2006; received in revised form 13 January 2007; accepted 17 January 2007

\begin{abstract}
Fresh stripe long-shoot bamboo (Bambusa dolichoclada Hayata) culm is attractive for its yellow and green stripes. The stripes, however, discolor quickly after harvest, and currently there is no method to preserve the colors. The objective of this study was to find methods to preserve the colorful yellow-green stripes. Results indicated that excellent color preservation was achieved by treating the bamboo culms with $1 \%$ copper nitrate in alcohol at $60^{\circ} \mathrm{C}$ for $2 \mathrm{~h}$. Such treatment could be shortened to $30 \mathrm{~min}$ by the aid of ultrasonic vibration during the treatment. Immersing bamboo culms in $1 \%$ copper nitrate alcohol solution at the ambient temperature for $4 \mathrm{~h}$ also achieved the same result. Treated specimens exhibited outstanding colorfastness and mildew resistance after 18 months of indoor exposure.
\end{abstract}

(C) 2007 Elsevier Ltd. All rights reserved.

Keywords: Bambusa dolichoclada; Stripe long-shoot bamboo; Color preservation; Colorfastness; Copper nitrate

\section{Introduction}

Bamboo is one of the most abundant non-timber forest resources in Asia [1], which has been used as construction materials, handicrafts and other purposes [2]. In Taiwan nearly 58 species and four varieties have been cultivated all over the country [3,4], including such important and special species as ma bamboo (Dendrocalamus latiflorus Munro), thorny bamboo (Bambusa stensotachys Hackel), green bamboo (Bambusa oldhamii Munro), makino bamboo (Phyllostachys makinoi Hayata), moso bamboo (Phyllostachys pubescens Mazel), stripe common bamboo (Bambusa vulgaris Schrad. ex Wendl. var. striata Gamble), convex giant bamboo (Bambusa vulgaris cv. Wamin Bambusa ventricosa), square bamboo (Chimonobambusa quadrangularis (Fenzi) Makino) and fernleaf hedge bamboo (Bambusa multiplex (Lour.) Raeuschel cv. Fernleaf Young). Among these species, the stripe common bamboo or stripe long-shoot bamboo (Bambusa dolichoclada Hayata) fascinates people with its bright alternating green and yellow vertical stripes. The bright green stripes fade quickly after

\footnotetext{
*Corresponding author. Tel.: + 886233664626 ; fax: + 886223654520 .

E-mail address: peter@ntu.edu.tw (S.-T. Chang).
}

being harvested. Therefore, it is desirable to find appropriate methods to preserve the colorful surface color of stripe long-shoot bamboo culms.

Several inorganic salts have been proven to be effective to preserve the green color of bamboo culms [5-9]. But there has been no report on color preservation of stripe long-shoot bamboo culms. It is known that ultrasonic waves can promote chemical reactions, and the technique has been employed in treating bamboo culms to preserve surface green color $[7,8]$. The objectives of this study were to search for simple methods for preserving and enhancement of the surface color of stripe long-shoot bamboo culms with environmentally friendly reagents and to investigate the effect of ultrasonic technique in such treatments.

\section{Materials and methods}

\subsection{Sample preparation}

Three-year-old stripe long-shoot bamboo (B. dolichoclada Hayata) culms were harvested from the experimental forest of National Taiwan University in Nan-Tou County. 
The bamboo culms were cut into $50 \mathrm{~mm}$ (longitudinal) $\times$ $15 \mathrm{~mm}$ (tangential) $\times 4 \mathrm{~mm}$ (radial) strips and stored at $4{ }^{\circ} \mathrm{C}$ in darkness prior to use.

\subsection{Chemical treatments}

Four water-borne salts (chromated phosphate (CP), copper phosphate $(\mathrm{CuP})$, copper azole $(\mathrm{CuAz})$ and ammoniacal copper quaternary compound-type B (ACQB) $[5,8,10]$, five alcohol-borne salts (copper sulfate $\left(\mathrm{CuSO}_{4}\right)$, copper acetate $\mathrm{Cu}\left(\mathrm{CH}_{3} \mathrm{COO}\right)_{2}$, copper nitrate $\mathrm{Cu}\left(\mathrm{NO}_{3}\right)_{2}$, copper chloride $\left(\mathrm{CuCl}_{2}\right)$ and copper hydroxide $\left.\mathrm{Cu}(\mathrm{OH})_{2}\right)$ and copper naphthenate $(\mathrm{CuN})$ containing $10 \%$ copper $[7,11]$ in xylene/ethanol $(1: 1, \mathrm{v} / \mathrm{v})$ were used in this study. Bamboo specimens were treated with salts of different concentrations $(0 \%, 0.25 \%, 0.5 \%, 1 \%, 2 \%$ and $4 \%)$ in a water bath at different temperatures $(25,40,60$, 80 and $100^{\circ} \mathrm{C}$ ) for $0.5,1,2,4$ and $6 \mathrm{~h}$. In addition to water bath treatments, specimens also were treated by immersing them in salt solutions at the ambient temperature for 1, 2, 4 and 6 days. Finally, the $1 \% \mathrm{Cu}\left(\mathrm{NO}_{3}\right)_{2}$ solution was selected to treat specimen in an ultrasonic bath at $60^{\circ} \mathrm{C}$ for $5,15,30,60,90$ and $120 \mathrm{~min}$. The ultrasonic bath used was Branson PC620 manufactured in USA with $180 \mathrm{~W}$ of power and an output frequency of $44 \mathrm{kHz}$. After treatment, all specimens were dried at $60^{\circ} \mathrm{C}$ for $12 \mathrm{~h}$ before color measurements.

\subsection{Color measurements}

Color measurement was performed with a colorimeter (Dr. Lange Co., Germany) with a $\mathrm{D}_{65}$ light source and a test-window diameter of $5 \mathrm{~mm}$. The tristimulus values $X, Y$ and $Z$ of all specimens were obtained directly with the colorimeter. Based on these data, the following color parameters were calculated: $L^{*}$ (value on the white/black axis), $a^{*}$ (value on the red/green axis), $b^{*}$ (value on the yellow/blue axis), $\Delta L^{*}$ (difference in brightness, $\Delta L^{*}=$ $\left.\left(L_{n}^{*}-L_{0}^{*}\right)\right), \Delta a^{*}$ (difference in $a^{*}$ component, $\Delta a^{*}=\left(a_{n}^{*}-\right.$ $\left.a_{0}^{*}\right)$ ), $\Delta b^{*}$ (difference in $b^{*}$ component, $\Delta b^{*}=\left(b_{n}^{*}-b_{0}^{*}\right)$ ), and $\Delta E^{*}\left(\right.$ color difference, $\left.\Delta E^{*}=\left[\left(\Delta L^{*}\right)^{2}+\left(\Delta a^{*}\right)^{2}+\left(\Delta b^{*}\right)^{2}\right]^{1 / 2}\right)$, where $L_{n}^{*}, a_{n}^{*}$ and $b_{n}^{*}$ were the $L^{*}, a^{*}$ and $b^{*}$ values of treated samples, respectively, and $L_{0}^{*}, a_{0}^{*}$ and $b_{0}^{*}$ were $L^{*}, a^{*}$ and $b^{*}$ values of the untreated reference, respectively. The above parameters were established by the Commission Internationale de l'Eclairage (CIE) in 1976 [6].

\subsection{Indoor exposure test}

Specimens treated with $1 \%$ alcohol-borne $\mathrm{Cu}\left(\mathrm{NO}_{3}\right)_{2}$ were exposed to indoor conditions to study their colorfastness. The specimens were placed in a room and exposed for 6,12 and 18 months to natural light $(\lambda>300 \mathrm{~nm})$ transmitted through a glass window during daytime. The average temperature and relative humidity during the study was $25 \pm 3{ }^{\circ} \mathrm{C}$ and $80 \pm 10 \%$, respectively. Mold growth on various bamboo specimens during indoor exposure was evaluated following the procedures described in the ASTM (D3274-82) standard [12].

\section{Results and discussion}

\subsection{Color changes of untreated and treated bamboo culms}

Colors of untreated culms faded after oven drying as indicated by increased $a^{*}$ value (from -5.1 to 2.0 ) of green color and varied $b^{*}$ and $L^{*}$ values of yellow color (from 36.4 and 59.9 to 27.4 and 69.1, respectively) (Table 1). Table 1 also shows results of treating bamboo culms with various $2 \%$ salt solutions at 60 or $100^{\circ} \mathrm{C}$ for $2 \mathrm{~h}$ in preserving colors. Based on $a^{*}$ values $\mathrm{Cu}\left(\mathrm{NO}_{3}\right)_{2}$ and $\mathrm{CuP}$ treatments were most effective, treatments with $\mathrm{CuSO}_{4}$, and $\mathrm{CuCl}_{2}$ and $\mathrm{CuN}$ were somewhat effective but treatments with $\mathrm{CP}, \mathrm{CuAz}, \mathrm{Cu}(\mathrm{OH})_{2}, \mathrm{Cu}\left(\mathrm{CH}_{3} \mathrm{COO}\right)_{2}$ and ACQ had no effect. In addition, the $\mathrm{Cu}\left(\mathrm{NO}_{3}\right)_{2}$ - and $\mathrm{CuP}$-treated specimens exhibited a slightly increased green brightness since the $L^{*}$ values increased from initial (fresh sample) 50.1 to 53.3 and 53.7, respectively. In lieu of the fact that ACQ was found effective in preserving the green color of makino bamboo ( $P$. makinoi Hayata) [10], the effectiveness of ACQ was further studied.

It has been pointed out that green color preservation is due to interactions between copper salts and chemical constituents of bamboo surface tissues $[13,14]$. Interactions between copper salts and cellulose, hemicelluloses, lignin and chlorophyll form stable and water-insoluble complexes during treatment, resulting in development and preservation of green color and excellent colorfastness.

\subsection{Effects of salt concentration, treating temperature and treating time}

Table 2 shows changes in $a^{*}$ and $\Delta E^{*}$ values of bamboo culms after treating with various concentrations of $\mathrm{Cu}\left(\mathrm{NO}_{3}\right)_{2}, \mathrm{CuP}$ and $\mathrm{ACQ}$ at 60 or $100^{\circ} \mathrm{C}$ for $2 \mathrm{~h}$. Specimens treated with $1 \% \mathrm{Cu}\left(\mathrm{NO}_{3}\right)_{2}$ at $60^{\circ} \mathrm{C}$ for $2 \mathrm{~h}$ not only exhibited the lowest $a^{*}$ value $(-7.5)$ but also a small $\Delta E^{*}$ (2.9). Results also show excellent green color preservation when specimens were treated with $0.5 \% \mathrm{CuP}$ $\left(a^{*}=-5.8 ; \quad \Delta E^{*}=1.6\right)$ and $0.25 \%$ ACQ $\left(a^{*}=-5.5\right.$; $\Delta E^{*}=2.5$ ). Table 3 presents results of the effect of treating temperatures on green color preservation. When treating time was fixed at $2 \mathrm{~h}$ the $a^{*}$ value of specimens treated with $1 \% \mathrm{Cu}\left(\mathrm{NO}_{3}\right)_{2}$ decreased with increasing treating temperature to a minimum of -7.5 at $60{ }^{\circ} \mathrm{C}$, while the $a^{*}$ values of specimens treated with $0.5 \% \mathrm{CuP}$ and $0.25 \%$ ACQ also decreased with increasing treating temperature and reached minimum values of -5.8 and -5.5 , respectively, at $100^{\circ} \mathrm{C}$. Because the $\mathrm{Cu}\left(\mathrm{NO}_{3}\right)_{2}$ treatment resulted in an $a^{*}$ value $\left(a^{*}=-7.5\right)$ lower than that of fresh samples $\left(a^{*}=-5.1\right)$, its effect was beyond preserving the original green color and the additional green color apparently was contributed to interactions between copper and cell wall constituents. 
Table 1

Color changes of stripe long-shoot bamboo after treating with $2 \%$ of various copper salts at 60 or $100^{\circ} \mathrm{C}$ for $2 \mathrm{~h}$

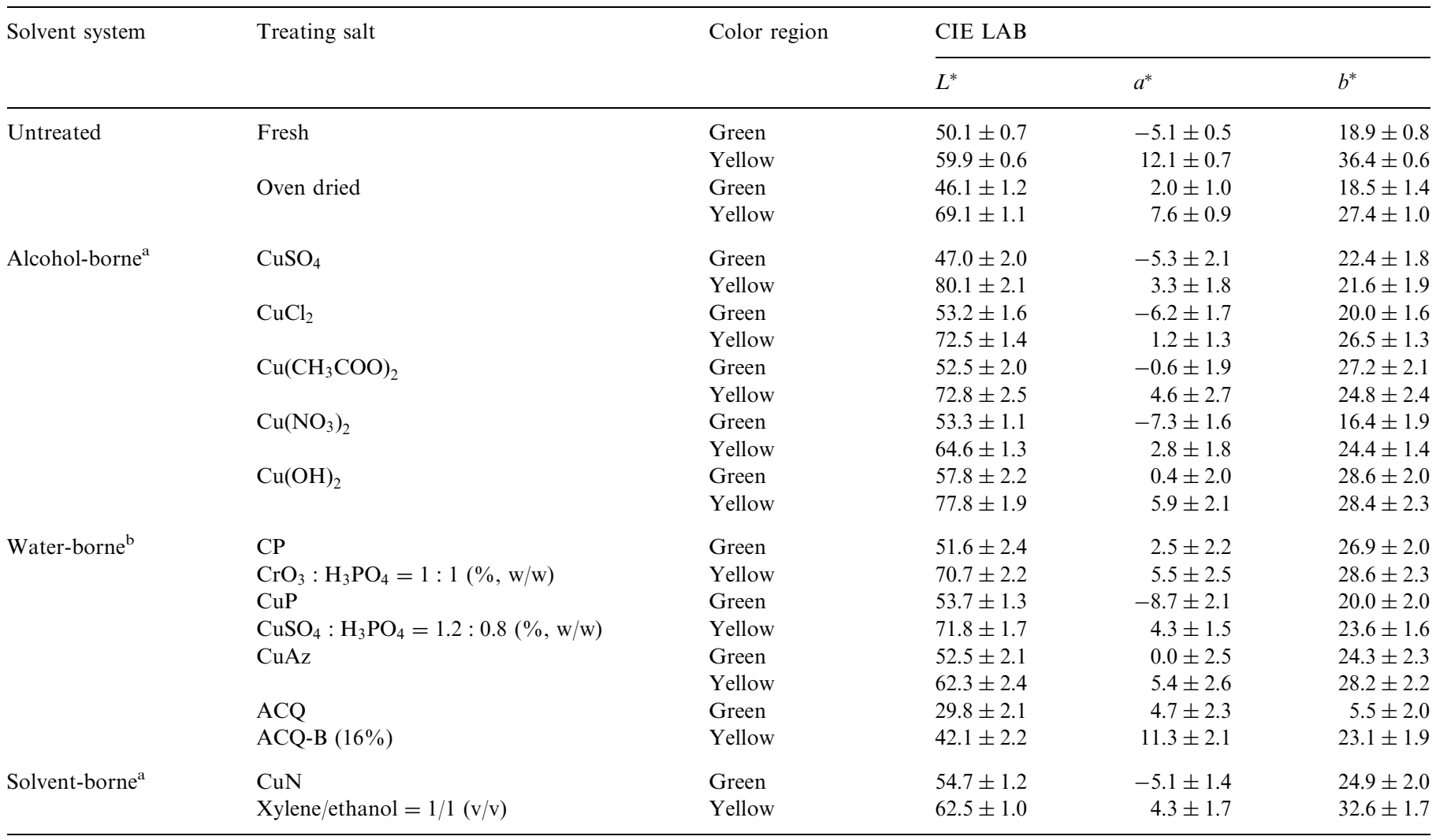

${ }^{\text {a }}$ Specimens were treated at $60^{\circ} \mathrm{C}$.

${ }^{\mathrm{b}} \mathrm{Specimens}$ were treated at $100^{\circ} \mathrm{C}$.

Table 2

Changes in the $a^{*}$ and $\Delta E^{*}$ values of stripe long-shoot bamboo after treating with different concentrations of $\mathrm{Cu}\left(\mathrm{NO}_{3}\right)_{2}, \mathrm{CuP}$ and $\mathrm{ACQ}$ at 60 or $100{ }^{\circ} \mathrm{C}$ for $2 \mathrm{~h}$

\begin{tabular}{|c|c|c|c|c|c|c|}
\hline \multirow[t]{2}{*}{ Conc. $(\%)$} & \multicolumn{2}{|l|}{$\mathrm{Cu}\left(\mathrm{NO}_{3}\right)_{2}{ }^{\mathrm{a}}$} & \multicolumn{2}{|l|}{$\mathrm{CuP}^{\mathrm{b}}$} & \multicolumn{2}{|l|}{$\mathrm{ACQ}^{\mathrm{b}}$} \\
\hline & $a^{*}$ & $\Delta E^{*}$ & $a^{*}$ & $\Delta E^{*}$ & $a^{*}$ & $\Delta E^{*}$ \\
\hline Untreated & $-5.1 \pm 0.5^{\mathrm{C}}$ & - & $-5.1 \pm 0.5$ & - & $-5.1 \pm 0.5$ & - \\
\hline 0 & $2.1 \pm 0.8^{\mathrm{A}}$ & 9.2 & $2.1 \pm 0.8$ & 9.2 & $2.1 \pm 0.8$ & 9.2 \\
\hline 0.25 & $-4.7 \pm 2.1^{\mathrm{B}}$ & 11.1 & $-5.0 \pm 1.2$ & 5.6 & $-5.5 \pm 2.0$ & 2.5 \\
\hline 0.5 & $-5.3 \pm 1.7^{\mathrm{C}}$ & 7.1 & $-5.8 \pm 1.7$ & 1.6 & $-4.5 \pm 2.3$ & 5.6 \\
\hline 1 & $-7.5 \pm 1.4^{\mathrm{D}}$ & 2.9 & $-5.3 \pm 1.4$ & 2.1 & $4.3 \pm 1.9$ & 21.8 \\
\hline 2 & $-7.3 \pm 1.6^{\mathrm{D}}$ & 3.7 & $-8.7 \pm 2.1$ & 4.0 & $4.7 \pm 2.3$ & 27.7 \\
\hline 4 & $-4.4 \pm 1.4^{\mathrm{B}}$ & 2.8 & $-3.8 \pm 2.3$ & 8.8 & $2.0 \pm 2.7$ & 23.1 \\
\hline
\end{tabular}

$a^{*}$ values marked with different letters are significantly different at the level of $p<0.05$ according to Scheffe's test.

${ }^{\text {a }}$ Specimens were treated at $60^{\circ} \mathrm{C}$.

${ }^{\mathrm{b}}$ Specimens were treated at $100^{\circ} \mathrm{C}$.

Fig. 1 shows the effect of treating bamboo culms with $1 \% \mathrm{Cu}\left(\mathrm{NO}_{3}\right)_{2}$ at $60{ }^{\circ} \mathrm{C}$ and with $0.5 \% \mathrm{CuP}$ and $0.25 \%$ ACQ at $100^{\circ} \mathrm{C}$ for various times on color changes. For the $1 \% \mathrm{Cu}\left(\mathrm{NO}_{3}\right)_{2}$ treatment green color faded initially when the reaction was carried out for only $30 \mathrm{~min}$ but steadily increased beyond $1 \mathrm{~h}$ reaction time as indicated by decrease in the $a^{*}$ values until a maximum green color was reached at 2 and $4 \mathrm{~h}$, followed by a decrease at $6 \mathrm{~h}$. A similar trend was found for the $0.5 \% \mathrm{CuP}$ and $0.25 \%$ ACQ treatments at $100^{\circ} \mathrm{C}$, in which maximum green color was reached at $2 \mathrm{~h}$ reaction time, followed by decreases at 4 and $6 \mathrm{~h}$.

These results clearly demonstrated that the $1 \%$ $\mathrm{Cu}\left(\mathrm{NO}_{3}\right)_{2}$ treatment at $60^{\circ} \mathrm{C}$ for 2 and $4 \mathrm{~h}$ was superior to all other treatments in enhancing the green color, while treatments with $0.5 \% \mathrm{CuP}$ and $0.25 \% \mathrm{ACQ}$ at $100^{\circ} \mathrm{C}$ for $2 \mathrm{~h}$ were only able to preserve the green color at the original 
Table 3

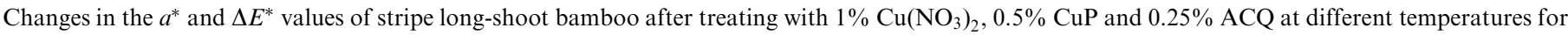
$2 \mathrm{~h}$

\begin{tabular}{|c|c|c|c|c|c|c|}
\hline \multirow[t]{2}{*}{ Temp. $\left({ }^{\circ} \mathrm{C}\right)$} & \multicolumn{2}{|l|}{$\mathrm{Cu}\left(\mathrm{NO}_{3}\right)_{2}$} & \multicolumn{2}{|l|}{$\mathrm{CuP}$} & \multicolumn{2}{|l|}{$\mathrm{ACQ}$} \\
\hline & $a^{*}$ & $\Delta E^{*}$ & $a^{*}$ & $\Delta E^{*}$ & $a^{*}$ & $\Delta E^{*}$ \\
\hline Untreated & $-5.1 \pm 0.5$ & - & $-5.1 \pm 0.5$ & - & $-5.1 \pm 0.5$ & - \\
\hline 25 & $2.6 \pm 3.7$ & 12.8 & $0.6 \pm 3.0$ & 6.5 & $-1.5 \pm 2.8$ & 4.1 \\
\hline 40 & $-2.7 \pm 3.4$ & 9.3 & $1.1 \pm 4.2$ & 8.5 & $-1.6 \pm 2.4$ & 7.0 \\
\hline 60 & $-7.5 \pm 1.4$ & 2.9 & $1.4 \pm 3.7$ & 8.8 & $-1.8 \pm 2.7$ & 5.3 \\
\hline 80 & - & - & $3.5 \pm 4.0$ & 11.8 & $-2.7 \pm 2.3$ & 11.4 \\
\hline 100 & - & - & $-5.8 \pm 1.7$ & 1.6 & $-5.5 \pm 2.0$ & 2.5 \\
\hline
\end{tabular}

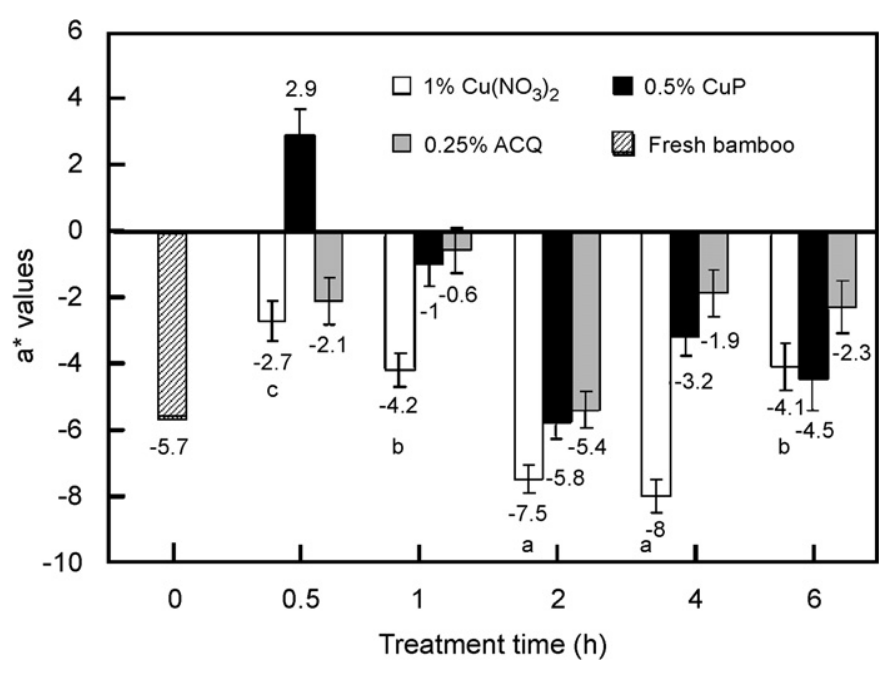

Fig. 1. Changes in $a^{*}$ value of stripe long-shoot bamboo culms after treating with $1 \% \mathrm{Cu}\left(\mathrm{NO}_{3}\right)_{2}$ at $60{ }^{\circ} \mathrm{C}$, and $0.5 \% \mathrm{CuP}$ and $0.25 \%$ ACQ at $100^{\circ} \mathrm{C}$ for different times (value marked by different letters are significantly different at the level of $p<0.05$ according to Scheffe's test).

level. Table 4 shows that the $1 \% \mathrm{Cu}\left(\mathrm{NO}_{3}\right)_{2}$ treatment time could be shortened to $30 \mathrm{~min}$ if the reaction was carried out in an ultrasonic bath, where the green color reached the same $a^{*}$ value $(-8.0)$ as that treated at $60^{\circ} \mathrm{C}$ for 2 or $4 \mathrm{~h}$ $\left(a^{*}=-7.5\right.$ to -8.0$)$ without the aid of ultrasonic bath. Table 4 also shows the effect of ultrasonic treatment on yellow color. After the ultrasonic treatment at $60^{\circ} \mathrm{C}$ for $30 \mathrm{~min}$, the yellow stripes had a least decrease in yellow color $b^{*}$ value $\left(\Delta b^{*}=8.1\right)$ and a least color change $\left(\Delta E^{*}=\right.$ 19.2) among all treating durations. The brightness $\left(L^{*}\right)$ of the yellow stripes also increased slightly from 59.9 to 62.4 . These results suggest that the ultrasonic treatment with $1 \%$ $\mathrm{Cu}\left(\mathrm{NO}_{3}\right)_{2}$ at $60^{\circ} \mathrm{C}$ for 30 min greatly enhanced the green color with little impact on yellow color.

\subsection{Colorfastness}

Table 5 presents results of colorfastness and mildew resistance of bamboo culms treated with $1 \% \mathrm{Cu}\left(\mathrm{NO}_{3}\right)_{2}$ at $60{ }^{\circ} \mathrm{C}$ for $2 \mathrm{~h}$ as compared to untreated samples. After 6,12 and 18 months of indoor exposure the $a^{*}$ values of untreated specimens steadily increased from -5.1 to $-0.4,1.8$ and 2.0 , respectively, while the corresponding $a^{*}$ values of treated specimens only increased from -7.5 to $-5.4,-4.9$ and -4.8 . As to changes in yellow color, the $b^{*}$ value of untreated specimens decreased from 36.4 to 26.6 $\left(\Delta b^{*}=9.8\right)$ after 18 months of indoor exposure and that of treated specimens only decreased from 27.2 to 24.3 $\left(\Delta b^{*}=2.9\right)$. These results indicate the remarkable colorfastness of specimens treated with $1 \% \mathrm{Cu}\left(\mathrm{NO}_{3}\right)_{2}$, in that after 18 months exposure to indoor light the specimens still maintained a green color very close to the fresh green color. Table 5 also shows that untreated specimens sustained some mold growths before drying out during indoor exposure, while the treated specimens totally prohibited mold growth on the surfaces.

\subsection{Dipping treatments}

Results of dipping treatments at the ambient conditions are shown in Fig. 2. The green color $a^{*}$ value reached a minimum reading of -11.2 when the specimens were immersed in alcohol solution of $1 \% \mathrm{Cu}\left(\mathrm{NO}_{3}\right)_{2}$ for 4 days. On the contrary, the green color of specimens treated with $1 \% \mathrm{CuP}$ and ACQ aqueous solutions faded continuously with immersion time. Difference in the effect of green color preservation between the alcoholic and aqueous salt solutions is attributed to much quicker penetration of the alcoholic solution than the aqueous solutions into bamboo tissues for the interactions between copper salt and tissue constituents to occur.

\section{Conclusions}

Treating stripe long-shoot bamboo culms with $1 \%$ $\mathrm{Cu}\left(\mathrm{NO}_{3}\right)_{2}$ in alcohol at $60^{\circ} \mathrm{C}$ for $2 \mathrm{~h}$ was able to enhance the green color and to preserve the yellow color in the beautiful alternating green and yellow stripes. Treating time could be shortened to $30 \mathrm{~min}$ when the treatment was carried out in an ultrasonic bath. The same result was obtained when the bamboo culms were treated by immersing them in $1 \% \mathrm{Cu}\left(\mathrm{NO}_{3}\right)_{2}$ alcohol solution at the ambient temperature for 4 days. Bamboo culms treated as such showed excellent color fastness after 18 months of 
Table 4

Changes in color parameters of stripe long-shoot bamboo culms after treatment with $1 \% \mathrm{Cu}\left(\mathrm{NO}_{3}\right)_{2}$ at $60{ }^{\circ} \mathrm{C}$ for different durations in ultrasonic bath

\begin{tabular}{|c|c|c|c|c|c|c|c|}
\hline \multirow[t]{2}{*}{ Treatment time (min) } & \multirow[t]{2}{*}{ Color region } & \multicolumn{3}{|l|}{ CIE LAB } & \multirow[t]{2}{*}{$\Delta a^{*}$} & \multirow[t]{2}{*}{$\Delta b^{*}$} & \multirow[t]{2}{*}{$\Delta E^{*}$} \\
\hline & & $L^{*}$ & $a^{*}$ & $b^{*}$ & & & \\
\hline \multirow[t]{2}{*}{ Fresh bamboo } & Green & $50.1 \pm 0.7$ & $-5.1 \pm 0.5$ & $18.9 \pm 0.8$ & - & & - \\
\hline & Yellow & $59.9 \pm 0.6$ & $12.1 \pm 0.7$ & $36.4 \pm 0.6$ & - & & - \\
\hline \multirow[t]{2}{*}{5} & Green & $47.6 \pm 1.6$ & $-0.2 \pm 2.4$ & $16.6 \pm 2.7$ & 4.9 & 2.3 & 13.3 \\
\hline & Yellow & $70.2 \pm 1.4$ & $6.7 \pm 2.2$ & $24.8 \pm 3.0$ & 5.4 & 11.6 & 24.4 \\
\hline \multirow[t]{2}{*}{15} & Green & $50.4 \pm 1.5$ & $-4.3 \pm 2.8$ & $26.4 \pm 2.9$ & 0.8 & 7.5 & 8.1 \\
\hline & Yellow & $69.2 \pm 1.8$ & $4.3 \pm 2.1$ & $23.7 \pm 2.4$ & 7.8 & 12.7 & 21.3 \\
\hline \multirow[t]{2}{*}{30} & Green & $48.9 \pm 1.7$ & $-8.0 \pm 2.4$ & $27.9 \pm 3.1$ & -2.9 & 9.0 & 3.1 \\
\hline & Yellow & $62.4 \pm 1.4$ & $5.8 \pm 2.5$ & $28.3 \pm 2.6$ & 6.3 & 8.1 & 19.2 \\
\hline \multirow[t]{2}{*}{60} & Green & $49.6 \pm 1.8$ & $-7.1 \pm 2.2$ & $22.8 \pm 3.0$ & -2.0 & 3.9 & 4.3 \\
\hline & Yellow & $68.4 \pm 1.1$ & $1.7 \pm 2.6$ & $26.2 \pm 2.8$ & 10.4 & 10.2 & 19.7 \\
\hline \multirow[t]{2}{*}{90} & Green & $50.1 \pm 1.3$ & $-6.1 \pm 2.0$ & $14.3 \pm 2.4$ & -1.0 & 4.6 & 7.8 \\
\hline & Yellow & $69.7 \pm 1.2$ & $4.3 \pm 2.3$ & $23.1 \pm 2.7$ & 9.4 & 13.3 & 20.5 \\
\hline \multirow[t]{2}{*}{120} & Green & $54.9 \pm 1.2$ & $-5.5 \pm 1.9$ & $25.6 \pm 2.3$ & -0.4 & 6.7 & 10.0 \\
\hline & Yellow & $72.4 \pm 1.0$ & $2.3 \pm 2.2$ & $23.4 \pm 2.9$ & 7.4 & 13.0 & 23.2 \\
\hline
\end{tabular}

Table 5

Color changes and mold growth of stripe long-shoot bamboo culms treated with $1 \% \mathrm{Cu}\left(\mathrm{NO}_{3}\right)_{2}$ after indoor exposure for 18 months

\begin{tabular}{|c|c|c|c|c|c|c|c|}
\hline \multirow[t]{2}{*}{ Exposure time (months) } & \multirow[t]{2}{*}{ Region of culm } & \multicolumn{3}{|c|}{ Untreated bamboo } & \multicolumn{3}{|c|}{ Treated bamboo ${ }^{\mathrm{a}}$} \\
\hline & & $a^{*}$ & $b^{*}$ & M.R. ${ }^{b}$ & $a^{*}$ & $b^{*}$ & M.R. ${ }^{b}$ \\
\hline \multirow[t]{2}{*}{0} & Green & $-5.1 \pm 0.5$ & $18.9 \pm 0.8$ & \multirow[t]{2}{*}{10} & $-7.5 \pm 1.4$ & $27.0 \pm 1.7$ & \multirow[t]{2}{*}{10} \\
\hline & Yellow & $12.1 \pm 0.7$ & $36.4 \pm 0.6$ & & $6.0 \pm 1.1$ & $27.2 \pm 1.3$ & \\
\hline \multirow[t]{2}{*}{6} & Green & $-0.4 \pm 2.1$ & $21.3 \pm 2.4$ & \multirow[t]{2}{*}{8} & $-5.4 \pm 1.7$ & $20.7 \pm 1.9$ & \multirow[t]{2}{*}{10} \\
\hline & Yellow & $8.4 \pm 1.9$ & $28.2 \pm 0.6$ & & $5.1 \pm 2.0$ & $25.6 \pm 1.6$ & \\
\hline \multirow[t]{2}{*}{12} & Green & $1.8 \pm 2.3$ & $17.9 \pm 2.0$ & \multirow[t]{2}{*}{8} & $-4.9 \pm 1.4$ & $17.7 \pm 2.1$ & \multirow[t]{2}{*}{10} \\
\hline & Yellow & $7.3 \pm 1.5$ & $27.1 \pm 0.9$ & & $4.5 \pm 1.6$ & $25.4 \pm 1.4$ & \\
\hline \multirow[t]{2}{*}{18} & Green & $2.0 \pm 2.2$ & $17.3 \pm 2.3$ & \multirow[t]{2}{*}{8} & $-4.8 \pm 1.2$ & $14.9 \pm 1.6$ & \multirow[t]{2}{*}{10} \\
\hline & Yellow & $6.9 \pm 1.8$ & $26.6 \pm 1.6$ & & $4.3 \pm 1.1$ & $24.3 \pm 1.5$ & \\
\hline
\end{tabular}

${ }^{\mathrm{a}}$ Green color protector dissolved in menthol and treated in $60^{\circ} \mathrm{C}$ for $2 \mathrm{~h}$.

${ }^{\mathrm{b}}$ Mildew resistance rating.

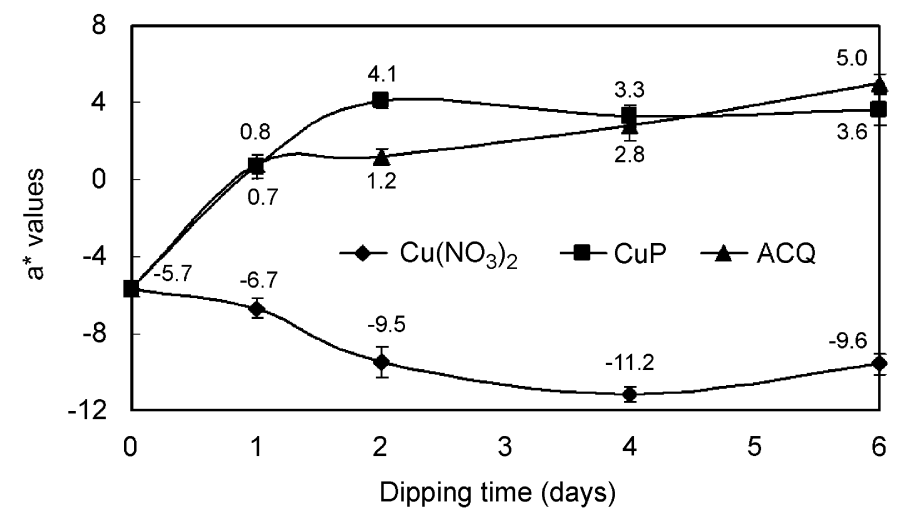

Fig. 2. Changes in $a^{*}$ value of stripe long-shoot bamboo culms after treating with $1 \% \mathrm{Cu}\left(\mathrm{NO}_{3}\right)_{2}$ in alcohol and $1 \% \mathrm{CuP}$ and ACQ in water at ambient temperature for different times.

indoor exposure. Treating bamboo culms with $0.5 \%$ copper phosphate and $0.25 \%$ ACQ aqueous solutions also were effective to preserve the colors at the fresh color levels.

\section{Acknowledgments}

This study was supported by a Grant (95-09.1-For-07(02)) from the Forestry Bureau of Council of Agriculture (COA) of the Executive Yuan, Taiwan. We thank the Forestry Bureau for financial support and the Experimental Forest of National Taiwan University for providing the bamboo samples.

\section{References}

[1] Hunter IR. Bamboo resources, uses and trade: the future? Journal of Bamboo and Rattan 2002;2:1-19.

[2] Wu SC. Research and development of the production and utilization of bamboo in Taiwan. Forest Products Industries 1982;1:18-24 [in Chinese].

[3] Lu CM. Cultivation and management of bamboo forests. Taiwan: Taiwan Forest Research Institute; 2001. 204pp

[4] Li TS. 20th century Taiwanese bamboo crafts. Taiwan: Artist; 2000. $191 \mathrm{pp}$.

[5] Chang ST, Wu JH. Green color conservation of ma bamboo (Dendrocalamus latiflorus) treated with chromium based reagents. Journal of Wood Science 2000;46:40-4. 
[6] Chang ST, Yeh TF. Effect of alkali pretreatment on surface properties and green color conservation of moso bamboo (Phyllostachys pubescens Mazel). Holzforschung 2000;54:487-91.

[7] Wu JH, Chung MJ, Chang ST. Evaluation of the effectiveness of alcohol-borne reagents on the green color protection of makino bamboo (Phyllostachys makinoi). Polymer Degradation and Stability 2004;83:473-9.

[8] Wu JH, Wu SY, Hsieh TY, Chang ST. Effects of copper-phosphorous salt treatments on green color protection and fastness of ma bamboo (Dendrocalamus latiflorus). Polymer Degradation and Stability 2002;78:379-84.

[9] $\mathrm{Wu}$ JH, Chung MJ, Chang ST. Green color protection of bamboo culms using one-step alkali-pretreatment-free process. Journal of Wood Science 2005;51:622-7.

[10] Chung MJ, Wu JH, Chang ST. Green color protection of makino bamboo (Phyllostachys makinoi) treated with ACQ and $\mathrm{CuAz}$ preservatives. Polymer Degradation and Stability 2005;90: $167-72$.

[11] Grace JK, Yamamoto RT, Laks PE. Evaluation of the termite resistance of wood pressure treated with copper naphthenate. Forest Products Journal 1993;43:72-6.

[12] American Society for Testing Materials. Evaluating degree of surface disfigurement of paint films by fungal growth of soil and dirt accumulation D3274. Easton, Maryland, 1984.

[13] Chang ST, Yeh TF, Wu JH. Mechanisms for the surface color protection of bamboo treated with chromated phosphate. Polymer Degradation and Stability 2001;74:551-7.

[14] Chang ST, Yeh TF, Wu JH, Hon DNS. Reaction characteristics on the green surface of moso bamboo (Phyllostachys pubescens Mazel) treated with chromated phosphate. Holzforschung 2002; 56:130-4. 